Greinin er ný í greinarflokknum antibiotika sem er samstarfsverkefni norrænna tannlæknablaða. Slík pemaverkefni, 8-10 greinar norrænna fræðimanna, hafa birtast árlega í öllum norrænu blöðunum nema okkar. Við hefjum samstarfið 2021. Greinin fjallar um tannlækningatúrisma, tilkomu hans og afleiðingar. Höfundar eru einir fremstu vísindamenn á Norðurlöndum á pessu sviði. Greinin er pýdd úr sænska tannlæknablaðinu, Tandvårdsturism - ökad risk för folkhälsan, Tandläkartidningen 2019;4:70-75. Hún er sérstaklega vönduð og pví tekin til birtingar hér.

\title{
Ferðamennska í tannlækningum - lýðheilsu stefnt í hættu
}

ØRJAN OLSVIK, PRÓFESSOR Í LAEKNISFRAEĐILEGRI ÖRVERUFRAEĐI Á HEILBRIGĐISVÍSINDASVIĐI NORGES ARKTISKE UNIVERSITET UIT Í TROMSÖ. YFIRRÁĐGJAFI HEILBRIGĐISSVIĐS DÝRALÆKNINGA, OSLÓ, NOREGI. BODIL KRISTINA LUND, PRÓFESSOR OG SÉRFRÆEĐINGUR Í KJÁLKASKURĐLAEKNINGUM, DEILD KLÍNÍSKRA TANNLAEKNINGA, HÁSKÓLANUM Í BERGEN, NOREGI. - DEILD KJÁLKASKURĐLAEKNINGA, HÁSKÓLASJÚKRAHÚSINU Í HAUKELAND, BERGEN, NOREGI. - TANNLAEKNADEILD, KAROLINSKA INSTITUTET, STOKKHÓLMI, SVÍPJÓĐ.

NETFANG: ORJAN.OLSVIK@UIT.NO TANNLAEKNABLAĐIĐ 2019; 37: 8-14

doi: 10.33112/tann.37.1.1

Undanfarið hefur svokölluð heilsutengd ferðamennska aukist til muna, en hún snýst um að sameina læknispjónustu erlendis og orlof. Heilsutengd ferðamennska getur skapað menningarleg, efnahagsleg, siðfræðileg, lagaleg og læknisfræðileg vandamál pegar smitsjúkdómar berast til heimalandsins. Sjúklingar sem kjósa að leita sér læknispjónustu erlendis ættu að vera meðvitaðir um að peir geta smitast af sýklalyfjapolnum bakteríum.

Alpjóðavæðing heilbrigðispjónustu sem er oft nefnd heilsutengd ferðamennska hefur aukist verulega á síðustu tíu árum [1]. Nú eru mörg stór fyrirtæki sérhæfð í að finna ódýra lækningaferðir um allan heim. Reiknað er með að heildarvirði heilsutengdrar ferðamennsku verði u.p.b. 700 milljarðar NOK á árinu 2017 eða tæpir 1.000 miljarðar ISK og áætlaður árlegur vöxtur um 25-35 prósent [2].

Fimm vinsælustu lönd heilsutengdrar ferðamennsku eru Tæland, Ungverjaland, Indland, Singapúr og Malasía. Meira en 70 prósent sjúklinga sem ferðast til Singapúr og Malasíu eru frá öđrum löndum Suðaustur-Asíu, en Bandaríkjamenn eru í miklum meirihluta sjúklinga sem sækja í slíka pjónustu í Tælandi og Indlandi. Flestir sem leita eftir ferðatannlækningum í Ungverjalandi eru borgarar Evrópusambandsins [3, 4].

Hafa verður í huga að heilsutengd ferðamennska skapar aukinheldur vandamál af efnahagslegum, menningarlegum, siðfræðilegum, lagalegum og læknisfræðilegum toga, að ógleymdum áhrifum á sjúklinga, ef ólæknandi smitsjúkdómar berast til heimalandsins [5, 6].

\section{Ferðamennska og tannlækningar}

Stór markaður hefur skapast fyrir tannlækningar og ferðamennsku. Sjúklingar ferðast til annarra landa til að fá ódýrari pjónustu, oft í tengslum við sumarfrí [7]. Bandaríkjamenn fara yfirleitt til nærliggjandi borga handan landamæra að Mexíkó til að sameina tannlækningar og sumarfrí. Sumir Bandaríkjamenn ferðast til Kosta Ríka eða til eyja í Vestur-Indíum. Á ári hverju leita 500 púsund Bandaríkjamenn sér tannlækninga erlendis. Í Asíu eru borgirnar Bangkok og Phuket í Tælandi pekktar fyrir ódýrar tannlækningar í háum gæðaflokki, en par er að finna tannlækna sem sótt hafa menntun sína víða um heim.

Innan Evrópu eru Ungverjaland og Pólland vinsælustu staðirnir fyrir ferðatannlækningar. Orlof par eru ekki eins veigamikill páttur og ferðalög til suðrænni landa, en verðlag 
er mjög lágt miðað við önnur Evrópusambandslönd [4, 8]. Ungverjaland er í næst efsta sæti lækningaferða en í efsta sæti hvað varðar ferðatannlækningar [8].

Ætla mætti að sjúklingar nýti sér oftast „heilsutengdar ferðaskrifstofur", en í reynd hafa aðeins 10\% nýtt sér slíka pjónustu. Um 42\% sjúklinga hafa fundið hana á internetinu og 73\% eftir ábendingar frá vinum og vandamönnum varðandi tilteknar tannlæknastofur [8].

Í bænum Mosonmagyaróvár í Ungverjalandi, við landamæri Austurríkis, búa um 32.000 manns og par starfa um 160 tannlæknar. Sjúklingar koma að mestu leyti frá Austurríki og peim megin við landamærin hafa nær allar tannlæknastofur lagt upp laupana [9].

Flestir ferðamenn sem leita sér tannlæknispjónustu í Ungverjalandi koma frá Englandi eða 30\%, 20\% frá Írlandi, 15\% frá Frakklandi og Austurríki ásamt 10\% frá Skandinavíu. Pegar tannlæknastofur skrá upprunaland sjúklinga sinna eru Pýskaland og Austurríki efst á lista með 45-50\%, par á eftir koma Írland og England með 21\%. Pólland var áđur fyrr helsti samkeppnisaðili Ungverjalands um ferðatannlækningar, en nú er Ungverjaland vinsælla hjá sjúklingum frá löndum innan ESB/EES [8].

Hvaða tannlæknispjónustu fá sjúklingar i ferðum sínum í Ungverjalandi? Gögn frá árinu 2010 sýna að 62\% fengu tannkrónur af einhverjum toga, 54\% tannplanta og 36\% stærri tannbrýr. Alls höfðu 31\% sjúklinga farið áđur i slíkar ferðir [8].

\section{Lágt verð tannlæknapjónustu í Ungverjalandi}

Verð á tannlæknapjónustu, allt frá hefðbundinni meðferð vegna tannskemmda til tannplantaaðgerða, er mun lægra í Ungverjalandi en t.d. í Englandi og Skandinavíu. Verð í Ungverjalandi getur verið allt að 30 til 70 prósent lægra og er líklega öflugasti hvati sjúklinga til slíkra ferða. Evrópusambandið ábyrgist gæði menntunar tannlækna og u.p.b. 25\% tannlækna sem leggja stund á nám við hina fjóra tannlæknaskóla fá kennslu á pýsku eða ensku. Flestar tannlæknastofur hafa hlotið ISO-vottun eða aðra gæðavottun sem er viðurkennd innan Evrópu og Bandaríkjanna.

Árið 2009 var hlutfall tannlækna í Ungverjalandi 48 tannlæknar á hverja 100.000 íbúa. Petta er lægra hlutfall en á Norðurlöndum, par sem 81 til 87 tannlæknar voru á hverja 100.000 íbúa pað ár [8].

pegar litið er til hvers vegna útlendingar sækja tannlæknispjónustu í Ungverjalandi segja 86\% sjúklinga kjósa Ungverjaland vegna lága verðsins, 35\% segja að gæðin ráði, 27\% til að sameina tannlæknispjónustu og orlof og
27\% til að komast hjá löngum biðlistum. Tölfræðin sýnir að 97\% sjúklinga eru ánægðir og 84\% mjög ánægðir með pjónustuna [8].

Hafa ber í huga að verð flugfarseðla innan Evrópu hefur lækkað umtalsvert á síðustu 20 árum og gott skipulag er á sumardvalarstöðum í Ungverjalandi, en hvort tveggja getur verið mikilvæg ástæða pess að Ungverjaland verður fyrir valinu.

\section{Norska ríkið fjármagnar tannlækningar erlendis}

Samkvæmt tilskipun EES eru skipti á heilbrigðispjónustu heimil á milli landa ESB og EES, eins og t.d. í Noregi. Allir sjúklingar geta pví fengið pá meðferð sem peir óska eftir ef peir greiða hana sjálfir. Reglusetning gildir síðan fyrir pá meðferð sem ríkið greiðir. Samkvæmt EES-tilskipuninni og tilheyrandi reglusetningum ber norska ríkinu að greiða peim sem vann verkið sömu upphæð og verkið hefði kostað í Noregi [10]. Tannlæknastofa í Noregi sem er viðurkennd af Helfo (Helseøkonomiforvaltningen, fjárlög stofnunarinnar eru um 34 milljarðar NOK) getur sent innheimtukröfu til ríkisins samkvæmt norskum lögum og gildandi gjaldskrá. Norska tannlæknastofan hefur kost á að meðhöndla sjúklinginn á eigin stofu eða á stofu samstarfsaðila í Ungverjalandi, sem vinnur verkið með mun minni tilkostnaði.

Hagnaðurinn verður eftir hjá norsku tannlæknastofunni, sem fær endurgreiðslu frá Helfo á norsku verðlagi, en

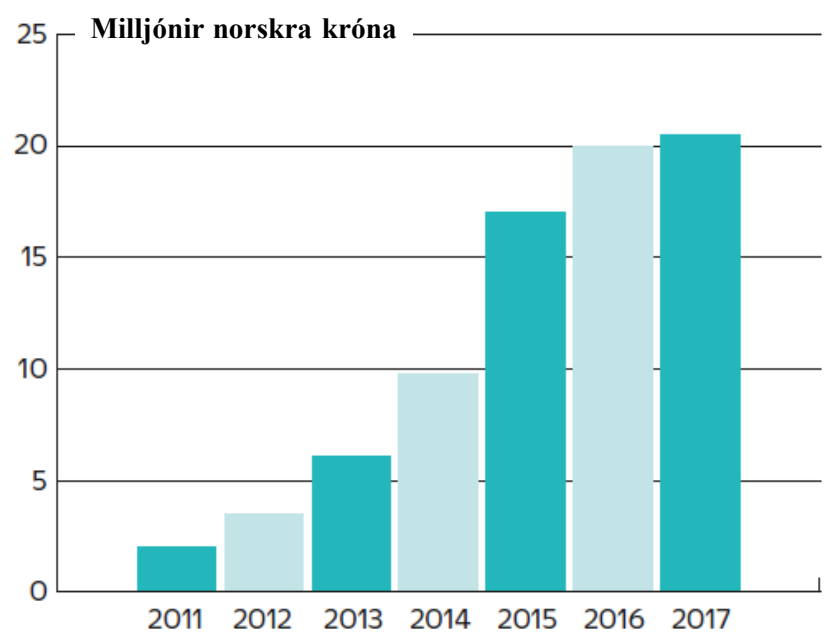

Mynd 1. Endurgreiðslur vegna tannlækniskostnaðar í milljónum NOK innan ESB samkvæmt EES-samningnum. Reglurnar eru nokkuð frábrugðnar i ESB-löndunum Svíbjóð, Danmörku og Finnlandi. Ríkisborgarar frá pessum löndum geta fengið endurgreiðslu vegna kostnaðar við tannlækningar, bæði á einkareknum og opinberum tannlæknastofum í öðrum löndum ESB. Endurgreiðslan er pó aðeins hámarksfjárhæð sem meðferð hefði kostað i heimalandi. 
Helfo meðhöndlar slík mál í Noregi. Útgjöld vegna tannlæknapjónustu erlendis sem Helfo greiðir fyrir hafa aukist úr 2 milljónum NOK árið 2011 i 20 milljónir NOK árið 2017 (Mynd 1) [10],

\section{Tannlækningaferðir hafa afleiðingar}

Ferðamenn sem leita sér tannlæknabjónustu erlendis greiða hærra verð en innlendir sjúklingar og pvinga pví innlenda sjúklinga af biðlistum og/eða keyra upp verð á pjónustunni. Aðeins er hægt að verja slíka starfsemi siðferðislega ef umfram afkastageta tannlækna er til staðar. í ljósi pess að hlutfall tannlækna á íbúa er u.p.b. 50 prósentum lægra t.d. í Ungverjalandi samanborið við Norðurlönd má teljast mjög ólíklegt að slík umframgeta sé til staðar [8]. Rök um að ferðamenn sem leita sér tannlæknapjónustu færi móttökulandi auknar tekjur eru í mikilli mótsögn við læknisfræðileg og siðfræðileg álitamál, p.e.a.s. aðgengi innfæddra að tannlæknispjónustu á viðráðanlegu verði. pegar verð fyrir tannlæknapjónustu ferðamanna er ekki hærra verða slíkar tekjur takmarkaðar svo lengi sem ekki er offramboð á tannlæknispjónustu.

Flestir ferðamenn sem leita sér tannlækninga i Ungverjalandi eru mjög ánægðir að meðferð lokinni [8]. Aðstæður verða pó öðruvísi ef vandamál koma í ljós eftir heimkomu. Sjúklingur verður að fara aftur til tannlæknis sem sá um meðferðina. Allir sjúklingar í Noregi njóta góðs af sjúklingatryggingu, en slík réttindi falla niður pegar meðferð á sér stað erlendis [12] og hið sama gildir í Svípjóð. pegar meðferð fer fram erlendis getur samband sjúklings og tannlæknis verið flókið með tilliti til aðgengis að sjúkraskrá, sjúkrasögu, perónulegri fagpekkingu o.s.frv. Margir norskir tannlæknar neita að taka við sjúklingum sem hafa fengið ranga meðferð erlendis. Slíkt á einnig við um notkun málma og plastblendi sem tannlæknar í Noregi pekkja ekki til eða vilja síður nota. Dæmi eru um norska sjúklinga sem neyðst hafa sjálfir að greiða tannlækningakostnað allt að 250.000 NOK, eftir að hafa fengið ranga meðferð erlendis [13, 14].

\section{Hætta af alvarlegum smitsjúkdómum}

Yfirleitt fela tannlækningar í sér hættu á dreifingu líkamsvökva eins og munnvatni og blóði en slíkur vökvi getur innihaldið smit- og sjúkdómsvaldandi bakteríur og veirur. Með góðu hreinlæti og dauðhreinsun áhalda er hægt að koma í veg fyrir að sýkingar berist á milli sjúklinga. Löggildar stofur vottaðar af vel pekktum stofnunum eiga að framfylgja sömu smitgát og tannlæknastofur á Norðurlöndum.

Ef smitgát er ábótavant getur pað stofnað sjúklingum i verulega hættu. Tannlæknastofum W. Scott Harrington í
Tulsa, Oklahoma var lokað árið 2013 eftir að yfirvöld komust að pví að dauðhreinsun áhalda milli sjúklinga var ábótavant, auk pess að almennu hreinlæti var einnig ábótavant. Fullyrt var i fyrirsögnum fjölmiðla að af 4.208 sjúklingum hefðu 96 smitast af lifrarbólguveiru C (HCV), fimm hefðu smitast af lifrarbólguveiru B og fjórir af HIV-veiru. Fullyrt var að a.m.k. einn sjúklingur hafi smitast af HCV af sýktu blóði [15].

David Acer tannlæknir á Jensen Beach í Flórída smitaðist árið1985 af HIV-veirunni við kynmök. Sex sjúklinga hans smituðust af sömu gerð HIV-veiru. Í upphafi var talið að hann hefði smitað sjúklinga sína viljandi, en við nánari eftirgrennslan kom í ljós að léleg smitgát hafi verið aðal orsakavaldur [16].

Sýklalyfjaónæmar bakteríur dreifast bæði með úða og með óbeinni og beinni snertingu. Tekið skal fram að pað er mjög krefjandi verkefni að koma í veg fyrir dreifingu á sjúkdómsvaldandi veirum og sýklalyfjaónæmum bakteríum.

Arizona-fylki í Bandaríkjunum liggur að landamærum Mexíkó. Nokkur fjöldi tannlæknastofa hefur sprottið upp nálægt landamærunum, en verðlag er mun lægra Mexíkó megin. Sjúklingar með eigin sjúkratryggingar eru oft sendir til meðferðar í Mexíkó par sem tryggingafélög hagnast af pví [17]. Sjúklingar snúa aftur heim án röntgenmynda og sjúkraskráa, en Ameriska tannlæknafélagið hefur lýst pví yfir að „, bandarískir tannlæknar fylgja siðfræðilegum viðmiðum og meðhöndla alla sjúklinga". Stærsta tryggingafélag Arizona ásamt tannlæknum settu af stað auglýsingaherferð sem bar titilinn "Trouble in Paradise: The untold story of Dental Tourism" (Klandur í paradís: Hin leynda saga ferðatannlækninga). Í bæklingi sem tengdist herferðinni var spurt: „Af hverju sækir bú tannlæknapjónustu í landi par sem pú gætir ekki hugsað pér að drekka drykkjarvatnið?". Mexíkóskir tannlæknar tóku herferðinni afar illa og henni var að lokum hætt [17].

Miðstöðvar forvarna gegn sjúkdómum (CDC) í Bandaríkjunum hafa gefið út ráđleggingar varðandi smitgát fyrir ferðamenn sem leita sér læknis- og tannlæknispjónustu erlendis [18] (Gögn 1)

\section{Sýklalyfjaónæmar bakteríur fylgja ferða- mönnum heim}

Nú er margsannað að heilsutengd ferðamennska er veigamikil orsök dreifingar sýklalyfjaónæmra baktería frá löndum par sem sýklalyf eru seld án lyfseðils og sýklalyfjapol er orðið stjórnlaust, til landa par sem hreinlæti er gott og minna ónæmi vegna takmörkunar á notkun sýklalyfja [19].

Árið 1996 tók Noregur upp eftirlitskerfi með sjúklingum sem dvalið höfðu á sjúkrahúsi utan Norðurlanda. Peir 


\section{Gögn 1. Heilræơi til lækningatúrista/tannlækningatúrista}

Spyrjið erlenda tannlækninn:

- Notar pú nýja hanska fyrir hvern sjúkling?

Takið eftir:

- Notar pú gufu- eða purrsæfingu til að dauð-

- Er stofan hrein og vel prifin? hreinsa áhöld á milli sjúklinga?

- Dauðhreinsar pú tannbora á milli sjúklinga?

- Pvo starfsmenn hendur með sápu og sótthreinsa milli sjúklinga?

- Notar pú nýjar deyfinganálar fyrir hvern sjúkling?

- Er vatnið sem notað er við skurðaðgerðir dauðhreinsað?

- Er vatn til skolunar dauðhreinsað.

- Eru hanskar alltaf notaðir?

- Nota starfsmenn einnota sótthreinsunarklúta á yfirborð sem getur mengast?

Heimild: Centers for Disease Control and Prevention $(C D C), U$

\section{Gögn 2. Skammstafanir fyrir sýklalyfjaónæmi} MOSA (MRSA)

- Skammstöfun á "methicillin ónæmum Staphylococcus aureus”.

- Lýsir stofnum af Staphylococcus aureus sem eru ónæmir fyrir penicillin. ESBL

- Skammstöfun á „breiðvirkum b (beta) laktamasa“ (e. „extended spectrum betalactamases“).

- Hugtak sem á við ensímahóp sem tilteknar bakteríur í pörmum geta framleitt.

- Ensímin geta brotið niður flest betalaktam sýklalyf að karbapenem undanskildu.

ESBLKARBA

- ESBL-ensím sem geta einnig brotið niður karbapenem sem er oft eina úrræðið við sýkingum af völdum baktería sem framleiða ESBL.

urðu að gangast undir próf hvort peir hefðu smitast af methicillin-ónæmum Staphylococcus aureus, MOSA (e. meticillinresistent Staphylococcus aureus, MRSA), ádur en peir fengu að starfa á eða leggjast inn á sjúkrahús í Noregi (Gögn 2). Samskonar reglur gilda í Svípjóð, Danmörku og Finnlandi (og Íslandi innskot ritst.). Petta eftirlitskerfi átti einnig við um starfsmenn sjúkrahúsa sem unnu með sjúklingum utan Norðurlanda. Slíkar varúđarráđstafanir eru mikilvægar til að draga úr dreifingu MÓSA, jafnvel pó að ekki hafi tekist komast fyrir alla dreifingu. Noregur hefur notið góðs af eftirlitskerf sínu í meira en 20 ár, en pví miður hefur talsvert af MÓSA samt borist inn í landið [20] (Mynd 2).

Sérstakt afbrigði MÓSA „Bengal Bay Clone” fannst hjá samtals 145 sjúklingum á norskum sjúkrahúsum á tímabilinu 2004-2014. Yfir 70\% smitbera "Bengal Bay Clone” voru af indverskum uppruna og talið er að heimsóknir á heilsugæslustöðvar og sjúkrahús erlendis skýri MÓSA-smitin [21]. Svipaðar rannsóknir sýna aukna tíðni sýklalyfjaónæmra baktería i saursýnum sem tekin eru eftir sumarfrí i asískum löndum [22].

Eftirlitskerfi með sýklalyfjaónæmi í Danmörku leiddi í ljós að MÓSA-smitaður tannlæknir smitaði tíu manns, par af nokkra sjúklinga sínna [23]. Breskur tannlæknir sem smitaðist af MÓSA á sjúkrahúsi par sem geisaði MÓSAfaraldur smitaði tvo af sjúklingum sínum. Hann notaði ekki hlífðarhanska við störf sín [24].

í Svípjóð hefur komið i ljós að sýkingarhætta af völdum baktería með alvarlegustu gerð sýklalyfjaónæmis ESBLKARBA, er mest við sjúkrahúsdvöl utan Norðurlanda. Frá pví að skimun hófst árið 2012 hefur á milli 68 og 86 prósent átt uppruna sinn erlendis frá. Flest tilvikin komu í kjölfar sjúkrahúsdvalar í Tyrklandi, Egyptalandi, Indlandi, Írak og Serbíu [25, 26].

Rannsókn á MÓSA í Seattle árið 2011 leiddi i ljós að 21\% tannlæknanema við Tannlæknaháskólann í Washington voru MÓSA-smitberar og bakterían fannst á 8,4\% yfirborði stóla og gólfa i fjórum af sjö tannlækningastofum háskólans. 


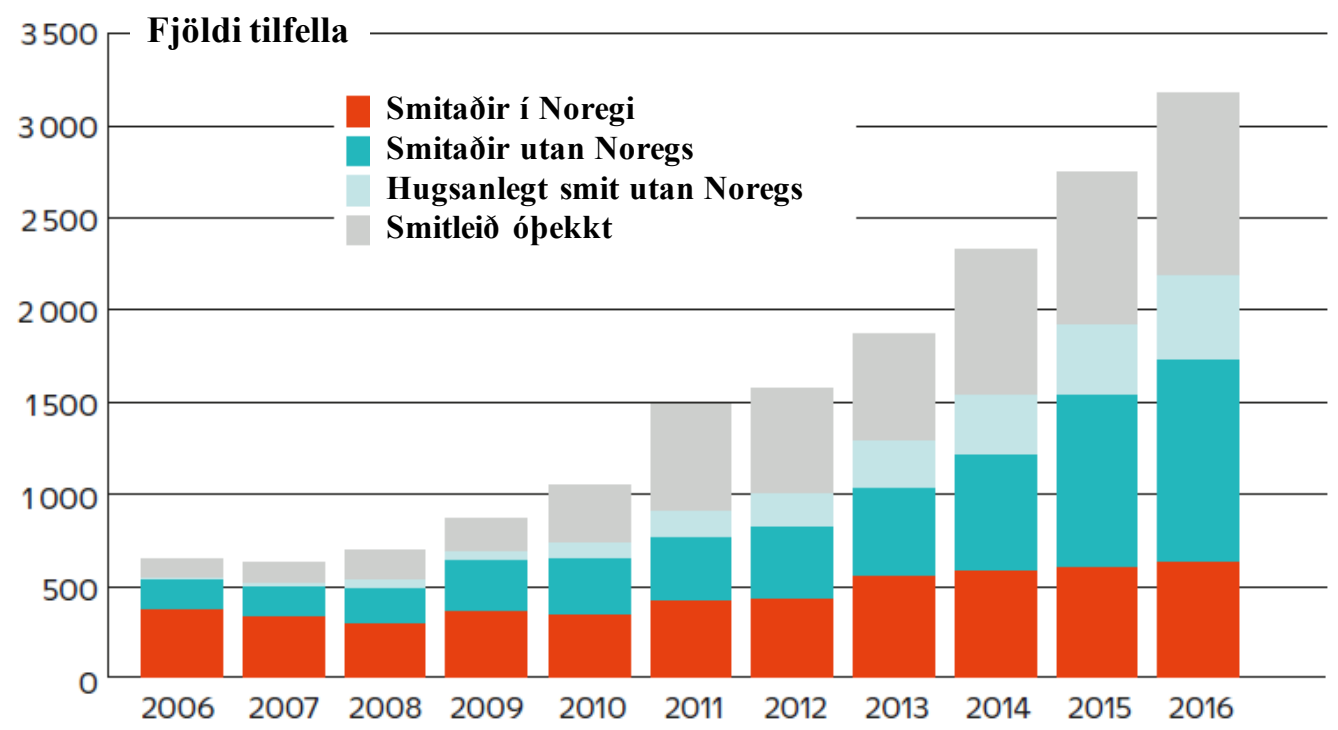

Mynd 2. Fjölgun MÓSA-jákvæðra sjúklinga í Noregi á árunum 2006-2016, skipt milli peirra sem smituðust í Noregi, utan Noregs, hugsanlega utan Noregs og peirra par sem ekki er vitað hvar smitið átti sér stað.

Við venjulegar aðstæður eru 1-2 prósent af almenningi MÓSA-smitberar. Ekki er vitað hvað orsakaði hátt hlutfall MÓSA í Seattle [27].

\section{Hindranir við lækningu smitsjúkdóma}

Í janúar árið 2008 kom sjúklingur á háskólasjúkrahúsið í Örebro með sýkingu sem ekki hafði svarað meðferð með karbapenemi né öðrum betalaktam-sýklalyfjum. Bakteríurnar í Örebro voru sérstakar að pví leyti að pær framleiddu ensím sem gat truflað öll pekkt afbrigði af betalaktam-sýklalyfjum og karbapenemi. Ensímið hefur fengið heitið „metallóbetalaktamasi frá Nýju-Delí nr. 1 " eða NDM-1 [28]. Genið sem gerir bakteríunni kleift að framleiða petta ensím getur færst á milli mismunandi stofna baktería og pannig komið í veg fyrir lækningu ólíkra smitsjúkdóma.

Bakterían hefur einnig fundist hjá sjúklingum í Evrópu, Bandaríkjunum, Kanada og Asíu og erfitt reyndist að lækna pessar sýkingar par sem bakteríurnar báru í sér NDM-1 genið [29-31]. Mesta skelfingu vakti að allir sjúklingarnir höfðu verið í Nýju-Delí í leit að ódýrri læknismeðferð. Um var að ræða heilsutengda ferðamenn sem höfðu tekið hinar óæskilegu og sýklalyfjaónæmu bakteríur með sér heim [28].

Fundist hafa karbapenem-ónæmar bakteríur hjá sjúklingum í Noregi, Svípjóð, Danmörku og Finnlandi og í flestum tilvikum hafa sjúklingar smitast erlendis. Fjöldi peirra eykst stöðugt og NDM-1 afbrigðið dreifist nú áfram til sjúklinga sem ekki hafa verið erlendis [20, 32-34].

\section{Pörf á samnorrænu átaki}

Hingað til hafa norrænar áætlanir um sýklalyfjameðferð og sýklalyfjaónæmi borið góðan árangur, bæði i búfjárrækt og innan heilbrigðiskerfisins. Hins vegar er hætta á auknum vandamálum pegar ónæmar bakteríur berast frá öðrum löndum [32-34].

Við vitum allt of lítið um tannlæknaferðir erlendis og sjúklinga sem bera MÓSA og aðrar hættulegar sýklalyfjaónæmar bakteríur með sér heim. Pað stafar af pví að sjúklingar sem leita sér tannlækninga erlendis eru ekki teknir með í núverandi eftirlitskerfi, prátt fyrir að mikið magn fyrirbyggjandi sýklalyfja sé notað i tannlækningum erlendis, sér í lagi við ísetningu tannplanta. Áhyggjuefni er að við ESB staðlað kerfisbundið eftirlit hefur komið í ljós 10-20 sinnum hærra hlutfall tilvistar MÓSA á lækningastofnunum í Ungverjalandi, en gerist á Norðurlöndunum [35, 26] (Mynd 3).

Búist er við að væntanlegt frumvarp til norskra laga um smitsjúkdóma eigi einnig við tannlæknastofur og að pær verði lagðar að jöfnu við skurðstofur sjúkrahúsa. Sömu reglur um áskilið eftirlit ættu pá að gilda um ferðatannlækninga erlendis og aðra sjúklinga sem koma frá sjúkrahúsum utan Norðurlanda. AEskilegt væri að festa samnorrænan aðgerðaramma í sessi gegn sýklalyfjaónæmi frá löndum sem nota sýklalyf pannig að alvarlegt vandamál skapist.

Einnig er vert að íhuga samninga ESB/EES um ríkisaðstoð við lækningaferðalög til landa par sem lækningakostnaður 


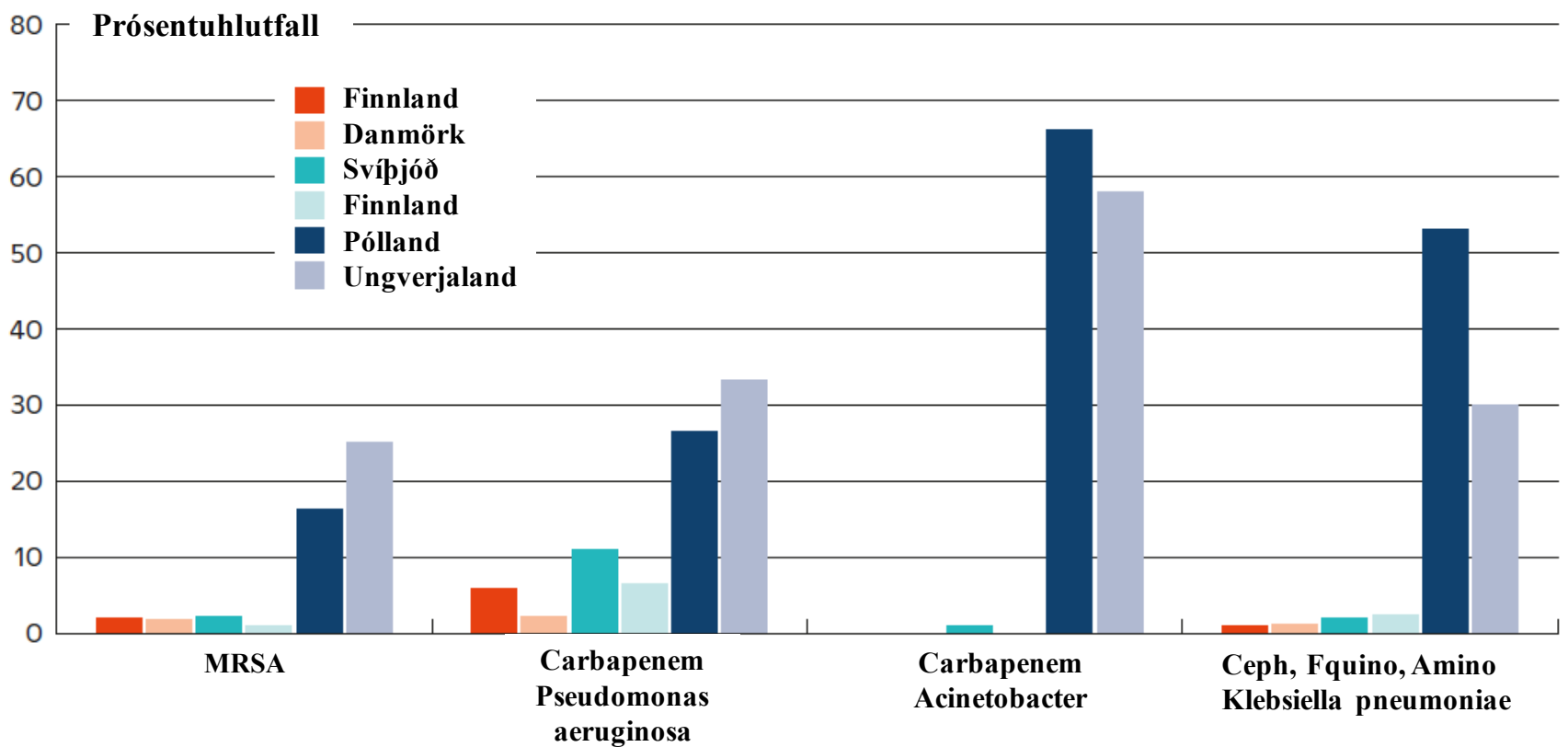

Mynd 3. Ónæmir bakteríustofnar eftir löndum.

er mjög lágur og hlutfall sýklalyfjaónæmra baktería er hátt, pegar fullnægjandi geta og fagkunnátta er til staðar á Norðurlöndum. Kostnaður við að berjast gegn innfluttum sýklalyfjaónæmum bakteríum getur verið mikill efnahagslega en jafnast pó ekki á við fórnarkostnað vegna heilsutjóns og mannslífa.

\section{Heimildir}

1. Kelley E. Medical tourism - WHO. http://fliphtml5.com/sbxk/uppu/basic

2. Medical tourism. https://en.wikipedia.org/wiki/Medical_tourism

3. Capella A. The world's 8 best countries for dental tourism https://www. liveandinvestoverseas.com/news/dental-tourism-destinations/

4. Medical tourism. Statistics \& facts. https://patientsbeyondborders.com/medical-tourismstatistics-facts

5. Centers for diseases control and prevention. Medical tourism. https://www.cdc.gov/ features/medicaltourism/index.html

6. Chen LH, Wilson ME. The globalization of healthcare: Implementations of medical tourism for the infectious disease clinician. Clin Infect Dis 2013; 57: 1752-9.

7. $\operatorname{Arg} A$, Guez G. Dental tourism. Dental Implant Update 2011; 22: 45-7.

8. Kovàcs $E$, Szòcska $G$, Török $B$, Ragàny $K$. Why is Hungary the main destination country in dental tourism? Why do patients choose Hungary for dental care? Hungarian case study on dental care and patient flow. Evaluating care across borders, European Union Cross Border Care Collaboration (ECAB). Semmelweis University 2013. http://semmelweis.hu/emk/files/2013/02/Final_case_study_web.pdf

9. Mosonmagyaróvár https://www.dentaly.org/us/dental-tourism-usa/dental-implantshungary

10. Helfo. Rapportering vedrørende pasientrettighets direktivet - folketrygdloven $§ 5-24 a$. 31-12-2017

11. Ortiz M. Dental tourism. Is the risk of "foreign" dental treatment worth the savings? https://www.rdhmag.com/articles/print/volume-31/issue-12/features/dental-tourism. html

12. Norsk pasientskade erstatning. https://www.npe.no/no/Om-NPE/aktuelt/Erstatningved-behandling-i-utlandet/
13. https://www.aftenposten.no/norge/i/kj8bk/Fikk-ekstraregning-pa-250000-ettertannbehandling-i-utlandet

14. Martinsen KB. En tannreise til Budapest i tre akter. Aftenposten 14 Nov 2016. https:// www.aftenposten.no/meninger/kronikk/i/d1ngq/En-tannreise-til-Budapest-i-tre-akter-Kristin-B-Martinsen

15. Bradley KK. Dental healthcare-associated transmission of Hepatitis C. Oklahoma State Department of Health. 2013. https://www.ok.gov/health2/documents/Dental\%20 Healthcare_Final\%20Report_2_17_15.pdf

16. CDC. Update: transmission of HIV infection during invasive dental procedures Florida. MMWR 1991; 40: 377-81.

17. KPBS. American head to Mexico for cheap dental care. http://www.kpbs.org/ news/2011/feb/09/medical-maquila-insurers-are-following-americans-m/

18. Nguyen DB, Gaines J. CDC Travellers health. 2017. https://wwwnc.cdc.gov/travel/ yellowbook/2018/the-pre-travel-consultation/medical-tourism

19. Hill TL. The spread of antibiotic-resistant bacteria through medical tourism and transmission prevention under the international health regulations. Chicago $\mathrm{J}$ Int Law 2011; 12: 273-308.

20. NORM/NORM-VET 2016. Usage of antimicrobial agents and occurrence of antimicrobial resistance in Norway. Troms $\varnothing$ / Oslo 2017. ISSN:1502-2307 (print) / 1890-9965 (electronic) https://unn.no/Documents/Kompetansetjenester,\%20 -sentre $\% 20$ og\%20fagråd/NORM $\% 20$ - $\% 20$ Norsk\%20 overvåkingssystem $\% 20$ for $\% 20$ antibiotikaresistens $\% 20$ hos $\% 20$ mikrober/Rapporter/NORM\%2ONORMVET\%202016.pdf

21. Blomfeldt A, Larssen KW, Moghen A, Gabrielsen C, Elstrøm P, Aamot HV, Jørgensen SB. Emerging multidrug-resistant Bengal bay clone ST772-MRSA-V in Norway: molecular epidemiology 2004-2014. Eur J Clin Microbiol Infect Dis 2017; 36: 1911-21.

22. Ostholm-Balkhed A, Tärnberg M, Nilsson M, Nilsson LE, Hanberger H, Hällgren A; Travel study group of southeast Sweden. Travel-associated faecal colonization with ESBL-producing Enterobacteriaceae: incidence and risk factors. J Antimicrob Chemother 2013; 68(9): 2144-53.

23. Larsen $T$, Kierulf $A$, Petersen $A$, Larsen AR. Multiresistente stafylokokker på tannklinikken. Tannlægebladet 2012; 116: 952/957.

24. Martin MV, Hardy P. Two cases of oral infection by methicillin-resistant Staphylococcus aureus. Br Dent J 1991; 170(2): 63-4.

25. Stenhen M, Ørtquist Å, Ringberg H, Larsson L, Olsson-Likjequist B, Hæggeman S, Kalin M, Ekdahl K. Imported methicillin-resistant Staphylococcus aureus, Sweden. Emerg Infect Dis 2010; 16: 189-96. 
26. Swedres-Svarm 2016. Consumption of antibiotics and occurrence of resistance in Sweden. Solna/Uppsala ISSN1650-6332.

27. Roberts MC, Soge 00 , Horst JA, Ly KA, Milgrom P. Methicillin-resistant Staphylococcus aureus from dental school clinic surfaces and students. Am J Infect Contr 2011; 39: 628-32.

28. Kumarasamy KK, Toleman MA, Walsh TR. Emergence of a new antibiotic resistance mechanism in India, Pakistan and the UK: a molecular, biological and epidemiological study. Lancet Infect Dis 2010: 597-602.

29. Kirby T. Timothy Walsh: introducing the world to NDM-1. Lancet Infect Dis 2012; 12: 189.

30. Kaul TK, Chhina DK. Medical tourism and New Delhi metallo beta-lactamase 1. A concern and treat. J Anaesth Clin Pharmacol 2010; 26: 437-8.

31. Nordmann P, Naas T, Poirel L. Global spread of Carbapenemase-producing Enterobacteriaceae. Emerg Infect Dis 2911; 17: 1891-8.
32. Tangdén T, Cars O, Melhus $\AA$, Løwdin E. Foreign travel is a major risk factor for colonization with Escherichia coli producing CTX-M-type extended-spectrum betalactamase: a prospective study with Swedish volinteers. Antimicrob Agents Chemother 2010; 54: 3564-8.

33. Kantele A, Lääveri T, Mero S, Vilkman K, Pakkanen SH, Ollgren J, Antikainen J, Kirveskari J. Antimicrobials increase travelers' risk of colonization by extendedspectrum betalactamase-producing Enterobacteriaceae. Clin Infect Dis 2015 Mar 15; 60(6): 837-46. doi: 10.1093/cid/ciu957. Epub 2015 Jan 21

34. Lunt N, Horsfall D, Hanefeldt J. Medical tourism: A snapshot of evidence on treatment abroad. Maturitas 2016, 88: 37-44

35. European Antimicrobial Resistance Surveillance Network. https://ecdc.europa.eu/en/ about-us/partnerships-and-networks/disease-and-laboratory-networks/ears-net

English Summary

\section{Medical and dental tourism - Consequences for public health}

ØRJAN OLSVIK. PROFESSOR, UIT, THE ARCTIC UNIVERSITY OF NORWAY, SCHOOL OF MEDICINE, TROMS $\varnothing$, NORWAY. NORWEGIAN COLLEGE OF VETERINARY MEDICINE, DEPARTMENT OF MICROBIOLOGY, OSLO, NORWAY. BODIL KRISTINA LUND, SENIOR CONSULTANT, PROFESSOR, DEPARTMENT CLINICAL DENTISTRY UNIVERSITY OF BERGEN. DEPARTMENT OF ORAL AND MAXILLOFACIAL SURGERY HAUKELAND UNIVERSITY HOSPITAL, BERGEN, NORWAY. DEPARTMENT OF DENTAL MEDICINE, KAROLINSKA INSTITUTET, STOCKHOLM, SWEDEN. ICELANDIC

DENTAL JOURNAL 2019; 37: 8-14

doi: 10.33112/tann.37.1.1

Global healthcare enables patients to choose where they want their treatment and at what price. Treatment for life threatening diseases, like cancer and open-heart surgery, can be found globally with prices as low as 80 percent of what is charged to patients in their home country. Such healthcare can be combined with vacations and the designation "medical tourists" is often used. Dental treatments, like oral surgery, implants, periodontitis and cosmetic dentistry, can also be often performed at substantially lower prices than in patient's home countries. However, the question arises as to whether this can be carried out without consequences? First of all, local patients should not be deprived of healthcare due even if medical tourists can pay more and the medical services should be of similar quality as in their home country. The increasing level of bacterial antibiotic resistance is a major concern worldwide. Our capability to efficiently treat some infections with antibiotics is being reduced year by year. The Nordic countries have for many years controlled patients and health care workers for possible contamination with resistant bacteria when arriving from other international hospitals. Therefore, it is important that patients seeking dental treatment outside the Nordic countries are aware of the possible danger and consequences of becoming infected or colonized by antimicrobial resistant superbugs.

The Nordic countries will in the future seek to have similar strategy combatting the increase of life threatening antibiotic resistant bacteria.

Correspondence: orjan.olsvik@uit.no 